\title{
BLOOD HEMATOLOGICAL AND BIOCHEMICAL PARAMETERS AND HUMORAL IMMUNITY AS AFFECTED BY ADDED DIETARY PROPOLIS SUPPLEMENTATION OF COBB BROILER CHICKS
}

\author{
A.M., Abdelsalam ${ }^{1}$, A.M. Abd ElAzim² ${ }^{2}$ A.M.R. Othman ${ }^{1}$, A. Makram² and E.M. Omar ${ }^{2}$ \\ ${ }^{1}$ Poultry Nutrition, Animal Production. Institute, Agriculture. Research Center. \\ ${ }^{2}$ Poultry Production Department, Faculty of Agriculture, Fayoum University, Egypt \\ Corresponding author: Adel Abdelsalam.E-mail adelsalam1@gmail.com
}

SUMMARY

$\mathrm{T}$ This experiment was carried out at El-Takamoly Poultry Project. The objective of this study was to evaluate the effect of dietary propolis supplementation on immune response of broiler chicks. A total number of 200 unsexed one day-old Cobb broiler chicks were used in this experiment; the chicks were divided into five groups, with four replicates of ten chicks each. Chicks were fed a starter diet without propolis supplementation during the first 6 days of age. At the 7 th day, birds were fed diets containing different levels of propolis $(0,200,400,600$ and $800 \mathrm{mg} / \mathrm{kg})$ till the end of 6 th weeks of age. Ethanolic extract of propolis was added to mixed diets. At 42 dy the blood hematological and biochemical parameters were determined, also , the hemagglutination- inhibition (HI) test was applied for determination of antibodies response in plasma and Commercial kits were used for detection of antibodies against nucleoprotein and matrix against of Newcastle disease (NDV) and avian influenza (AIDV). The present result revealed that the hematocrit level of chicks fed diet containing 400, 600 or $800 \mathrm{mg}$ propolis was significantly $(\mathrm{P} \leq 0.05)$ higher than that of control-group. With respect to plasma total protein and globulin, it could be speculated that the supplemental propolis at 400, 600 or $800 \mathrm{mg}$ significantly increased plasma total protein and globulin compared to control group, also there was highest antibodies concentration is related to 400, $600 \mathrm{and} 800 \mathrm{mg} / \mathrm{kg}$ propolis treatments for AI and ND, but $200 \mathrm{mg} / \mathrm{kg}$ propolis were not different from control group. There was no effect of propolis observed on Infectious bronchitis (IB) titration. In conclusion, the propolis may have positive effect on blood biochemical and humoral immunity of broilers.

Keywords; Propolis, Broiler chicks' nutrition, Hematological, Biochemical Humoral immunity.

\section{INTRODUCTION}

Many countries tend to prohibit use of antibiotics as growth promoters because of their adverse effects as their residual problems in tissues and eggs of birds. Supplementation of natural components in poultry ration is now widely distributed in the world. These components are served as growth promoting, which are healthful and help to improve the production performance of animal and poultry without any harmful effect (El-Ghamry., et al 2002 and Abdelsalam et al., 2018). There are considerable reports which confirm the positive effects of natural flavonoids on immune system of different species. These studies are almost focused on antibody synthesis, $\mathrm{T}$ lymphocyte stimulation, increasing blood lymphocytes, phagocytosis activity, thymus and bursa of fabricious weight are several factors which have been considered in this relation (Kong et al., 2004). Beginning of the humoral and cellular immune response is mainly related to the cytokines released from activated T cells stimulated by ethanol extract of propolis (Scheller et al., 1988) .

In addition to its immune system booster, propolis is an excellent natural antibiotic (Bratter et al., 1999). The addition of propolis to the diet produce a positive effect on weight gain and improve the digestive utilization of iron and the regeneration efficiency of hemoglobin (Haro et al., 2000). Propolis has a strong anti-bacterial activity, in addition to antifungal, antiviral and antiprotozoal properties (Scheller et al., 1999) Thus, the objective of the present study was to evaluate the effect of extracted propolis on blood parameters and humoral immunity of the broilers. 


\section{Abdelsalam et al.}

\section{MATERIALS AND METHODS}

The experimental work of the present study was carried out at El-Takamoly Poultry project, Fayoum Governorate. A total number of 200 of unsexed one day-old Cobb broiler chicks were used in this experiment; the chicks were grown in floor brooder and were fed on experimental diet without propolis supplementation for one week of age.Chicks were fed a starter diet without propolis supplementation during the first week, at the $7^{\text {th }}$ day of age, birds were fed diets containing different levels of propolis $(0,200,400$, 600 and $800 \mathrm{mg} / \mathrm{kg}$ ) till the end of $6^{\text {th }}$ weeks of age. Ethanolic extract of propolis was added to mixed diets.

\section{Parameters tested}

\section{Hematological and blood biochemical parameters:}

At the end of experiment, Blood samples were collected from birds ( $5 \mathrm{ml}$ from brachial vein). Each blood sample from each individual was divided into two samples, one in a heparinized test tube for blood hematological parameters, and the other in a non-heparinized test tube for biochemical parameters, and then serum was separated by centrifuging at $4000 \mathrm{rpm}$ for 15 minutes. The clear serum samples were carefully drawn and transferred to dry, clean, small glass bottles and stored at $-20^{\circ} \mathrm{C}$ in a deep freezer until the time of chemical determinations. The biochemical characteristics of blood were calorimetrically determined using commercial kits.

\section{Humoral immunity}

At 42 days of age, hemagglutination- inhibition (HI) test was applied for determination of antibodies response in plasma samples according to OIE Manual (2005). Commercial kits were used for detection of antibodies against nucleoprotein and matrix against of NDV and AIDV.

Hemagglutination- inhibition (HI) test titter regarded as positive if there is inhibition at serum dilution of $1 / 16(4 \log 2)$. as well as titter against IB (infection bronchitis disease) were estimated in the serum of immunized birds using The enzyme-linked immunosorbant assay ( ELISA) technique ( ELISA is an extremely sensitive test that is used to detect antibodies or specific antigens).

\section{Statistical analysis:}

Data were analyzed using general linear model procedure of SPSS software SPSS, (1999). Significant differences among treatment means were determined using Duncan's multiple range test Duncan, (1955) According to the following model:

$$
\mathbf{Y}_{\mathrm{ij}}=\boldsymbol{\mu}+\mathbf{T}_{\mathrm{i}}+\mathbf{e}_{\mathrm{ij}}
$$

Where; $\mathrm{Y}_{\mathrm{ij}}=$ Trait measured, $\mu=$ Overall means, $\mathrm{T}_{\mathrm{i}}=$ Treatment effect $(\mathrm{i}=1-5), \mathrm{e}_{\mathrm{ij}}=$ Experimental error.

\section{RESULTS AND DISCUSSION}

\section{Blood parameters:}

\section{Hematological parameters:}

Effects of experimental diets on broilers' blood parameters are presented in table (1). The hematological parameters tested in current study include red and white blood cell counts, hemoglobin concentration and hematocrit percentage. Hematological parameters are usually related to health status and are of diagnostic importance in clinical evaluation of the state of health. Blood parameters are good indicators of physiological, pathological and nutritional status of an animal and changes in hematological parameters have the potential of being used to elucidate the impact of nutritional factors and additives supplied in diet on any living creature. For example, leucocytes are known to increase sharply when infection occurs, as they are one of the first lines of defense of the body (Ganong, 1999).

The hematological values obtained in this study indicated no detrimental impact of Propolis on RBCs, WBCs counts and hemoglobin content. The present result revealed that there was no significant difference between control and $200 \mathrm{mg}$ propolis diet for hematocrit level. Inversely, the hematocrit level of chicks fed 
diet containing 400, 600 or $800 \mathrm{mg}$ propolis was significantly ( $\mathrm{P} \leq 0.05)$ higher than that of control-group. The higher hematocrit level may have enhanced oxygen delivery to the tissue (Zongo and Petitjean, 1990). Also, this increase is supposed to be caused by increased blood volume as a reaction to increasing body oxygen requirement. Reports on the effect of propolis supplementation on blood hematological parameters are very scarce.

Table (1): Hematological parameters (Means \pm SE) of birds fed different levels of propolis supplementation.

\begin{tabular}{lcccccc}
\hline \multirow{2}{*}{ Item } & \multicolumn{5}{c}{ Propolis $(\mathrm{mg} / \mathrm{kg}$ diet $)$} & \multirow{2}{*}{ SE } \\
\cline { 2 - 5 } & 0 & 200 & 400 & 600 & 800 & 0.39 \\
Hemoglobin & 10.03 & 10.15 & 10.38 & 9.85 & 10.23 & 0.17 \\
RBC & 2.73 & 2.91 & 2.88 & 2.72 & 2.76 & 0.39 \\
WBC & 12.64 & 13.62 & 13.73 & 14.03 & 13.20 & 0.70 \\
Hematocrit level,\% & $36.25^{\mathrm{b}}$ & $36.25^{\mathrm{b}}$ & $38.75^{\mathrm{a}}$ & $39.00^{\mathrm{a}}$ & $38.50^{\mathrm{a}}$ & 0 \\
\hline a,... $b$ values in the same row within the same item followed by different superscripts are significantly different (at P $\leq$ \\
0.05 for a to).
\end{tabular}

\section{Biochemical parameters:}

Effect of supplemental propolis on some blood constituent of broiler chicks are summarized in table (2). With respect to plasma total protein, it could be speculated that the supplemental propolis at 400, 600 or 800 mg significantly $(\mathrm{P} \leq 0.01)$ increased plasma total protein compared to control group. Similar reports were drawn by Giurgea et al. (1981). They indicated that daily administration of propolis extract to chickens changed the blood concentration of cholesterol, total proteins and amino acid. Also, Propolis stimulated mammalian tissue regeneration, as it caused strong activation of mitosis of cells cultured in vitro and it enhanced protein biosynthesis (Gabrys et al., 1986). Similar trend was not observed for albumin, whereas there was no significant difference among treated groups for plasma albumin. Concerning plasma globulin, our result revealed that the plasma globulin was significantly $(\mathrm{P} \leq 0.01)$ increased when the propolis was added to the diet at 400,600 or $800 \mathrm{mg}$. The globulins are composed of three fractions, designated alpha, beta and gamma. Alpha-globulins are a group of proteins manufactured almost entirely by the liver. Normally, these proteins increase with acute nephritis, severe active hepatitis, usually systemic inflammation, malnutrition and in nephritic syndromes (Galal et al., 2008). The gammaglobulin fraction contains most of the immuno-proteins, including $\operatorname{IgM}, \operatorname{IgA}, \operatorname{IgE}$ and $\operatorname{IgG}$. These usually elevate with ongoing antigenic stimulation, usually from infectious agents (Galal et al., 2008). In accordance to A/G ratio, Non significant differences have been recorded. But numerical differences were obtained. These findings in turn have influenced the $\mathrm{A} / \mathrm{G}$ ratio as it is declined in treated groups 400,600 and $800 \mathrm{mg}$ compared to 0 and 200 $\mathrm{mg}$. This reduction may reflect an enhancement of bird's immunity. The A/G ratio has been well known as an indicator for the metabolic activities and immune resistance. In birds, the low $\mathrm{A} / \mathrm{G}$ ratio indicates more disease resistance and immune response (Griminger, 1986).

With respect to liver function, it could be noticed that supplemental Propolis at 400, 600 and $800 \mathrm{mg}$ significantly reduced ALT $(\mathrm{P} \leq 0.01)$ and AST $(\mathrm{P} \leq 0.05)$ concentration compared to control-group. Hegazi et al. (1997) showed that, administration of Egyptian and Bulgarian propolis induces an antibacterial activity in vivo as well as in vitro. The ethanolic extract of propolis has a weak general effect on estimated parameters in normal rats and it is not a toxic substance. Both types of propolis exerted an anabolic effect for protein synthesis by liver cells. Both types of infections with $S$. aureus and E. coli caused an increase in the activity in serum AST \& ALT and consequently decrease their activity in the liver. On the other hand, the activity of ALT and AST returned to the control level after administration of propolis in rats infected with S. aureus and E. coli 
Table (2): Biochemical parameters (Means \pm SE) of birds fed different levels of propolis supplementation.

\begin{tabular}{|c|c|c|c|c|c|c|}
\hline \multirow{2}{*}{ Item } & \multicolumn{5}{|c|}{ Propolis (mg/kg diet) } & \multirow{2}{*}{ SE } \\
\hline & 0 & 200 & 400 & 600 & 800 & \\
\hline Total Protein, $(\mathrm{g} / \mathrm{dl})$ & $2.73^{\mathrm{C}}$ & $2.80^{\mathrm{BC}}$ & $3.03^{\mathrm{AB}}$ & $3.08^{\mathrm{A}}$ & $3.25^{\mathrm{A}}$ & 0.08 \\
\hline Albumin, (g/dl) & 1.63 & 1.65 & 1.70 & 1.73 & 1.90 & 0.09 \\
\hline Globulin $(\mathrm{g} / \mathrm{dl})$ & $1.10^{\mathrm{B}}$ & $1.15^{\mathrm{B}}$ & $1.33^{\mathrm{A}}$ & $1.35^{\mathrm{A}}$ & $1.35^{\mathrm{A}}$ & 0.05 \\
\hline $\mathrm{A} / \mathrm{G}$ ratio & 1.48 & 1.45 & 1.30 & 1.28 & 1.42 & 0.11 \\
\hline $\mathrm{ALT}, \mathrm{U} / \mathrm{L}$ & $9.33^{\mathrm{A}}$ & $9.17^{\mathrm{A}}$ & $7.67^{\mathrm{B}}$ & $7.33^{\mathrm{B}}$ & $7.67^{\mathrm{B}}$ & 0.42 \\
\hline AST, U/L & $210.33^{\mathrm{a}}$ & $210.50^{\mathrm{a}}$ & $192.17^{\mathrm{ab}}$ & $190.33^{b}$ & $188.17^{\mathrm{b}}$ & 6.01 \\
\hline
\end{tabular}

$a, \ldots b$, and $A, . . C$, values in the same row within the same item followed by different superscripts are significantly different (at $P \leq 0.05$ for a to $b ; P \leq 0.01$ for $A$ to $C$ ).

\section{Humoral immunity:}

The results are shown in table (3). As monitored in this Table, there is significant difference $(\mathrm{P} \leq 0.01)$ between antibody content of the serum against avian influenza (AI), and significant difference $(\mathrm{P} \leq 0.05)$ between antibody content of the serum against Newcastle disease (ND). Highest concentration is related to 400,600 and $800 \mathrm{mg} / \mathrm{kg}$ propolis treatments for $\mathrm{AI}$ and ND, but $200 \mathrm{mg} / \mathrm{kg}$ propolis were not different from control group. There was no effect of propolis observed on infectious bronchitis (IB) titration. These results indicate that propolis may have positive effect on humoral immunity of broilers.

Stimulation of immune system by natural products has already been reported (Hegazi et al., 1995 and Kong et al., 2004). Not only in broilers, but also in rodents. These effects of propolis have been confirmed (Blonska et al., 2004 and Giurgea et al., 1983). The effect of natural products such as propolis on immune system of different species is interesting and complicated. The direct effect might be related to stimulating the lymphatic tissue in the digestive system, and indirect effect via changing the microbial population of the lumen of GIT. At the moment there is no specific answer to this question, but it is very obvious that propolis is able to enhance the immune response to different antigenic stimulants even in mouse (Scheller et al., 1988). Propolis is a natural product which in numerous experiments has revealed different actions on immune system. For example, increasing the macrophage activity (Dimov et al., 1991), changing microbial populations in the stomach and intestine lumen and stimulating lymphatic tissues (Taheri et al., 2005), increasing the IL 1 (Bratter et al., 1999; Havsteen, 1983; Ivanovska et al., 1995 and Orsolic and Basic, 2003), IL2 (Ivanovska et al., 1995) and IL4 (Park et al., 2004). In this relation increasing the humoral response in broilers might be related to combination of these responses. Because it is very obvious that in immune system B lymphocytes are stimulated by these cytokines, and then they are changed to plasma cells which would be able to produce antibodies. On the other hand propolis have anti-oxidant (Kumazawa et al., 2004; Nagei et al., 2003 and Russo et al., 2002) and anti-inflammatory (Borrelli et al., 2002 and Dimov et al., 1991) effects, and these are related to inhibition of prostaglandin synthesis (Namgoong et al., 1994 and Toma et al., 1981) as an anti-immune substance and resulting better humoral response. One point which should be mentioned is about the influenza antibody that was raised against natural infection from the environmental serotypes without any vaccination, which the response might be much lower than forced vaccination. It seems interesting to fractionate the propolis and study the effect of each fraction individually, to realize its real action on immune system (Taheri et al., 2005).

Table (3): Antibody titrations against different viruses of birds fed different levels of propolis supplementations

\begin{tabular}{|c|c|c|c|c|c|c|}
\hline \multirow{2}{*}{ Virus } & \multicolumn{5}{|c|}{ Propolis (mg/kg diet ) } & \multirow{2}{*}{$\mathrm{SE}$} \\
\hline & 0 & 200 & 400 & 600 & 800 & \\
\hline $\mathrm{AI}^{*}$ & $6.25^{\mathrm{C}}$ & $6.25^{\mathrm{C}}$ & $7.50^{\mathrm{AB}}$ & $8.25^{\mathrm{A}}$ & $8.00^{\mathrm{AB}}$ & 0.23 \\
\hline ND** & $6.25^{\mathrm{b}}$ & $6.25^{\mathrm{b}}$ & $7.00^{\mathrm{ab}}$ & $7.50^{\mathrm{a}}$ & $7.50^{\mathrm{a}}$ & 0.30 \\
\hline $\mathrm{IB} * * *$ & 3771.25 & 3079.75 & 3101.50 & 2951.00 & 4735.75 & 545 \\
\hline
\end{tabular}




\section{CONCLUSION}

Generally, it can be concluded that propolis as a natural feed additive have positive effect on humoral immunity of broilers and blood parameters.

\section{REFERENCES}

Abdelsalam, A.M., A.M. Abd El-Azzim. A.M.R. Othman, A. Makram and E.M. Omar. 2018. Effect of Dietary Propolis Supplementation on Growth Performance of Cobb Broiler Chicks. The 10th International Poultry Conference (Poster) from 26-29 November(2018). Sharm Elsheikh., Cairo, Egypt. 43-51.

Blonska, M. ; Bronikowska, J. ;Pietsz, G. ; Czuba, Z. ; Scheller S. and Krol, W. (2004). Effects of ethanol extract of propolis (EEP) and its flavones on inducible gene expression in J774A.1 macrophages. J. Ethnopharmacology, 91: 25-30.

Borrelli, F.; Maffia, P.; Pinto, L.; lanaro, A.; Russo, A.; Capasso, F. and lalenti, A. (2002). Phytochemical compounds involved in the anti-inflammatory effect of propolis extract. Fitoterapia, 73: 353-363.

Bratter, C.; Tregel, M.; Liebenthal C. and Volk, H. (1999). Prophylactic effectiveness of propolis for immunostimulation: a clinical pilot study. Forsch Komplementarmed, 6: 256-260.

Bratter, C.; Tregel, M.; Liebenthal C. and Volk, H. (1999). Prophylactic effectiveness of propolis for immunostimulation: a clinical pilot study. Forsch Komplementarmed, 6: 256-260.

Dimov, V.; Ivanovska, N.; Manolova, N.; Bankova, V.; Nikolav, N. and Popov, S. (1991). Immunomodulatory action of propolis. Influence on anti infectious protection and macrophage function. Apidologie, 22: 155-162.

Duncan, D. B. (1955). Multiple range and multiple F-test. Biometrics, 11: 1-42.

El-Ghamry, A. A.; El-Mallah, G.M., and El-Yamny, A. T. (2002). The effect of incorporating yeast culture, Nigella sativa seeds and fresh garlic in broiler diets on their performance. Egypt. Poult. Sci. 22 (11):445459.

Gabrys, J.; Konecki, Z.; Krol, W.; Scheller, S. and Shani, J. (1986). Free amino acids in bee live product (propolis) as identified and quantified by gas Liquid chromatography. Pharmacological Research Communications 18 (6): 513-518.

Galal, A.; Abd El-Motaal, A. M.; Ahmed, A.M.H. and Zaki T.G. (2008). Productive performance and immune response of laying hens as affected by dietary propolis supplementation. International Journal of Poultry Science; 7 (3):272-278.

Ganong, W.F. (1999). Review of Medical Physiology. 19th ed. Stanford, Connecticut, Appleton and Lange, p. 353 .

Giurgea, R.; Toma, V.; Popescu, H. and Polinicencu, C. (1981). Effects of standardized propolis extract on certain blood constituents in chickens. Clujul Medical, 54(2): 151-154.

Giurgea, R.; Popescu, H. and Polrencu, C. (1983). Effect of standardized propolis extract (S.P.E) on immune reactions. Clujul Medical, 56(1): 73-76.

Griminger. P. (1986). Lipid metabolism in "AVIAN PHYSIOLOGY" edited by P. D. Strukie. $4^{\text {th }}$ ed. Springer-Verlag, Inc.,New Work, NY.

Haro, A.; Lopez-Aliaga, I.; Lisbona, F.; Barrionuevo, M.; Alfereaz, M. J. and Campos, M. S. (2000). Beneficial effect of pollen and /or propolis on the metabolism of iron, calcium, phosphorus and magnesium in rats with nutritional ferropenic anemia. J. Agric. Food Chem.2000, 48 (11): 5715-5722.

Havsteen, B. (1983). Flavonoids, a class of natural products of high harmacological potency. Biochemical Pharmacology, 32: 1141-1148. 


\section{Abdelsalam et al.}

Hegazi A. G.; El Miniawy H. F. and El Miniawy F. A. (1995). Effect of some honeybee products on immune response of chicken infected with Virulent NDV. Egyptian J. Immuol. 2 (2): 79-86.

Hegazi, A. G.; Khalefa M. and Toussun, E. (1997). Influence of various types of propolis on some biochemical changes of normal and bacterial infected rats. International Symposium On Apitherapy, Cairo 8-9th, March, 1997.

Ivanovska, N.; Nechev, H.; Stefanova, Z.; Bankova V. and Popov, S. (1995). Influence of cinammic acid on lymphatic proliferation, cytokine release and Klebsiella infection in mice. Apidologie, 26: 73-81.

Kong, X., Y. Hu, R. Rui, D. Wang and X. Li, (2004). Effects of Chinese herbal medicinal ingredients on peripheral lymphocyte. International Immunopharmacology, 4: 975-982.

Kumazawa, S.; Hamaska T. and Nakayama, T. (2004). Antioxidant activity of propolis of various geographic origins. Food Chem., 84: 329-339.

Nagei, T.; Inoue, R.; Inoue, H. and Suzuki, N. (2003). Prepartion and antioxidant properties of water extract of propolis. Food Chem., 80: 29-33.

Namgoong, S.Y.; Son, K. H.; Chang, H. W.; Kang, S. S. and Kim, H. P. (1994). Effects of naturally occurring flavonoids on mitogen-induced lymphocyte proliferation and mixed lymphocyte culture. Life Sci., 54: 313-320.

OIE. Manual. (2005). Manual of Diagnostic Tests and Vaccines for Terrestrial Animals. PART 2 section 2.1 chapter 2.1. World Organization for Animal Health, Paris, France.

Orsolic, N. and Basic, I. (2003). Immunomodulation by water-soluble derivative of propolis: a foctor of antitumor reactivity. J. Ethnopharmacology, 84: 265-273.

Park, J. H.; Lee, J. K.; Kim, H. S.; Chung, S.T.; Eom, J. H.; Kim, K. A.; Chung, S. J.; Paik S. U. and Oh, H.Y. (2004). Immunomodulatory effect of caffeic acid phenethyl ester in Balb/c mice. International Immunopharmacology, 4: 429-436.

Russo, A.; Longo, R. and Vanella, A. (2002). Antioxidant activity of propolis: role of caffeic acid phenthyl ester and galangin. Fitoterapia, 73: S21-S29.

Scheller, S.; Gazda, G.; Pietsz, G.; Szumlas, J.; Eckert J. and Shani, J. (1988). The ability of ethanol extract of propolis to stimulate plaque formation in immunized mouse spleen cells. Pharmacological Research Communications, 20: 323-328.

Scheller, S.; Gazda, G.; Pietsz, G.; Szumlas, J.; Eckert J. and Shani, J. (1988). The ability of ethanol extract of propolis to stimulate plaque formation in immunized mouse spleen cells. Pharmacological Research Communications, 20: 323-328.

Scheller, S.; Dworniczak, S.; Waldemar-Klimmek, K.; Rajca, M.; Tomczyk, A. and Shani, J. (1999). Synergism between ethanolic extract of propolis and anti-tuberculosis drugs on growth of mycobacteria . Z. Naturforsch [C] 1999, Jul., 54 (7-8): 549-553.

SPSS, For Windows (1999). User Guide: Statistics. Version 10. SPSS Inc. Chicago, IL, USA.

Taheri, H. R.; Rahmani H. R. and Pourreza. J. (2005). Humoral immunity of broilers is affected by oil extracted propolis (OEP) in the diet. Intl. J. Poult. Sci. 4:414-417.

Toma, V.; Popescu H. and Polinicencu, C. (1981). Effect of standardized propolis extracts on certain blood constituents of chicken. Clujul Medical, 54: 151-154.

Zongo, D. and Petitjean, M. (1990). Effects associated with the Na (naked neck) gene in the domestic cock. Bulletin of Anim. Health and Prod. in Africa. 38: 3, 259-263. 
تأثر مكونات الدم الخلوية والبيوكيميائية والمناعة المصلية باضافة البروبليس في علائق سلالة دجاج الكب

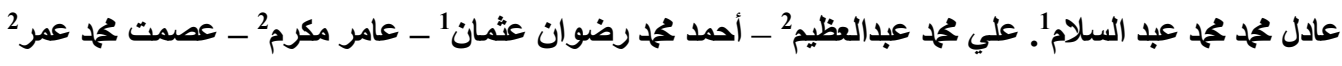

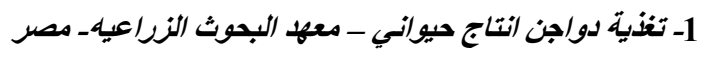

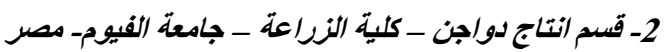

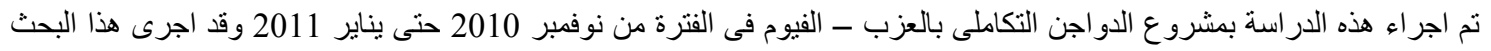

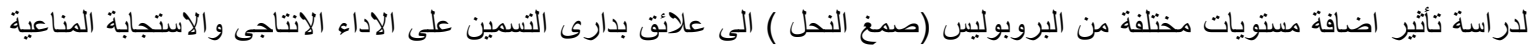

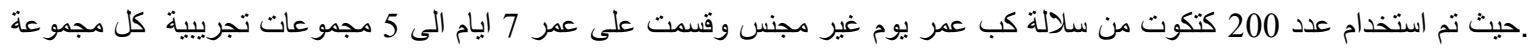

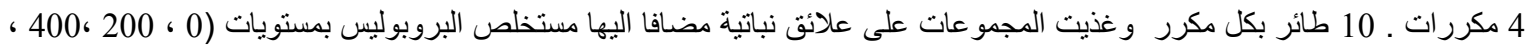

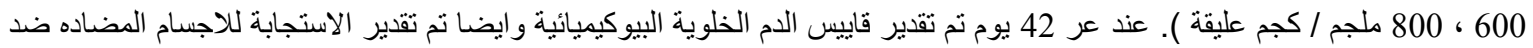

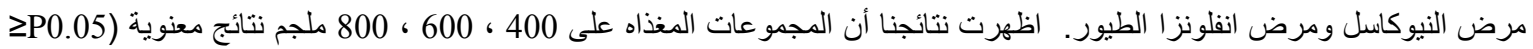

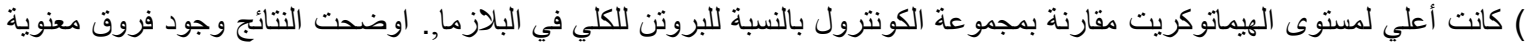

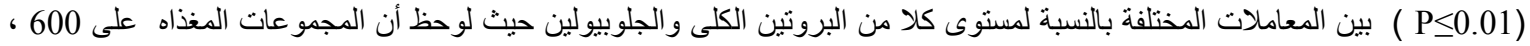

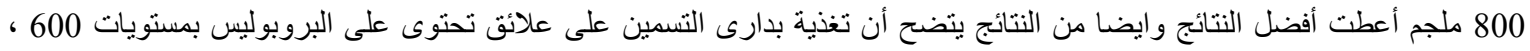

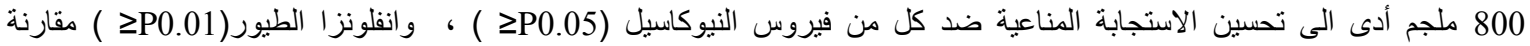

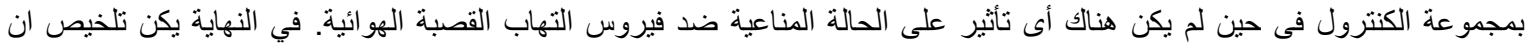
اضافة البروبليس له تأثير ايجابي علي مكونات الدم البيوكيميائية واليناعة المصليه. الكلمات اللداله: بروبليس - تغذية دجاج التسمين - الدكونات الخلويهـ البيوكيمبائيه - الدناعة الدصليه 